\title{
ДОСЛІДЖЕННЯ САМОСВІДОМОСТІ У НАВЧАЛЬНІЙ РОБОТІ ЗІ СТУДЕНТАМИ-ПСИХОЛОГАМИ
}

\begin{abstract}
Анотація. У статті висвітлені особливості та хід застосування дослідницького підходу до вивчення самосвідомості у навчальній роботі зі студентами-психологами. Здійснений огляд наукових публікацій за обраною темою; з'ясовані підходи до дослідження самосвідомості. Розглянуті особливості вивчення самосвідомості з позицій різних підходів. Висвітлена специфіка залучення студентів до дослідження самосвідомості, як при проведенні аналітичної, так і практичної частини дослідження. Дослідження полягало у створенні раціонального підходу до ознайомлення студентів із вивчення самосвідомості, який би дозволив поєднати наявні знання 3 даної теми на певній оптимальній основі, подати їх доступно й у відповідній логічній послідовності, виходячи з їхніх потреб у таких знаннях, наявного рівня знань і чинних вимог професійної підготовки. Зроблені висновки з проведеної роботи і намічені перспективи подальших досліджень у даному напрямку. Ключові слова: підготовка майбутніх фахових психологів, навчальний процес, дослідження самосвідомості, формування фрахової компетентності.
\end{abstract}

Vyntyuk Yuriy

National University "Lviv Polytechnic"

\section{STUDY OF CONSCIOUSNESS IN TRAINING ACTIVITIES WITH PSYCHOLOGY STUDENTS}

Summary. The article highlights the features and course of application of the research approach to the study of self-awareness in educational work with students-psychologists. A review of scientific publications on the selected topic; approaches to the study of self-awareness are clarified. Peculiarities of studying self-consciousness from the standpoint of different approaches are considered. The specifics of involving students in the study of self-awareness are highlighted. The research consisted of an attempt to develop and test a rational approach to acquainting students with the study of self-awareness, which would combine existing knowledge on this topic on a relevant basis, present them in an appropriate logical sequence, based on their needs for such knowledge, the existing level. knowledge and current requirements for professional training of psychologists. The study provides both analytical and practical components; it is organized and conducted by the teacher, but with the maximum possible involvement of students. At the same time, the traditional presentation of the material during the classes on mastering this topic was not planned; instead, before attending classes, students had to get acquainted with the material of each subsequent lecture, and during the classes it was planned to study it: clarify unclear provisions, clarify and specify certain points, for example, in the form of conversation or debate, etc. Students had to show the ability to independently process the material intended for study, as well as to be involved in the process of resolving issues submitted for consideration. Much greater opportunities for research on the topic provides a practical part of the study, which is to demonstrate the possibilities of working with self-awareness in the practice of a professional psychologist: both the features of manifestation and diagnosis and formation of indicators. The result of the research work was that students not only better understood the role of self-awareness in everyday life, educational and professional activities, their purpose, features and manifestations, but also found out the possibilities of applying the acquired knowledge in future professional activities. In conclusion, conclusions are drawn from the work done and the prospects for further research in this area are outlined.

Keywords: training of future professional psychologists, educational process, research of self-consciousness, formation of professional competence.

$\Pi$ остановка проблеми. Докорінна реорганізація системи освіти, вищої передусім, вимагає застосування нових підходів до підготовки фахівців різних спеціальностей. Сучасні підходи вимагають, щоб студенти під час навчання опанували не тільки необхідні їм у майбутньому теоретичні знання, але й практичні способи їхнього застосування, необхідні в повсякденній діяльності за певним фрахом. Це стосуеться і підготовки майбутніх фрахових психологів, так як тільки володіння необхідними знаннями разом із засвоєними практичними вміннями і необхідними навичками здатне забезпечити їм необхідний рівень профресійної компетентності. Відтак постає потреба надати їм під час навчання належну підготовку до діяльності в сучасних, ринкових умовах, для забезпечення високої професійної конкурентоспроможності. До таких вимог у наш час дедалі частіше потрапляе вміння працювати 3 самосвідомістю; дана обставина зумовлюе актуальність і доцільність даного дослідження.

Метою роботи $є$ висвітлити особливості та хід застосування дослідницького підходу до вивчення самосвідомості у навчальній роботі зі студентами-психологами.

Завдання дослідження:

- здійснити огляд наукових публікацій за обраною темою; з'ясувати підходи до дослідження самосвідомості;

- розглянути особливості вивчення самосвідомості з позицій різних підходів;

- висвітлити специфіку залучення студентів до дослідження самосвідомості;

- зробити висновки з проведеної роботи і намітити перспективи подальших досліджень у даному напрямку. 
Дана робота є продовженням попередніх досліджень, із формування професійної компетентності майбутніх фахових психологів, які були опубліковані раніше (див., напр.: [2]).

Аналіз останніх досліджень і публікацій. Загалом праць за темою дослідження виявлено не багато, як вітчизняних, так і закордонних авторів. Серед них варто відзначити, зокрема, публікації: Р. Бернса [1], О. С. Гуменюк [3], О. Захарової [4], І. Кона [6], С. Д. Максименка [7], Л. Мітіної [8], О. Морозової [9], П. А. Мясоїда [10], І. В. Орлової [11], С. Л. Рубінштейна [13], М. В. Савчина [14], О. Спіркіна [15], В. Століна [16], Л. Г. Терлецької [17], О. Тітаренко [18], Г. Цукермана та Б. Мастерова [19], І. Чеснокової [20], колективні збірники [5; 12] та деякі інші.

У них розглянуті питання сутності самосвідомості; ï фрункщії, складові та їхні особливості; висвітлено основні проблеми, що постають при вивченні даного фоеномену; наведено інформацію про основні підходи до їі дослідження; розглянуто структуру самосвідомості особистості та особливості iii функціонування; висвітлено прикладний аспект застосування знань про самосвідомість; з'ясовано шляхи і способи розвитку самосвідомості, а також розглянуто стан сучасних досліджень у даному напрямку. Одержана в результаті вивчення вказаних публікацій інформація використана при організації і проведенні власного дослідження.

Виділення не вирішених раніше частин загальної проблеми. Незважаючи на те, що основні підходи до дослідження самосвідомості у наявній науковій літературі з даної тематики висвітлені достатньо повно, інформації про те, як саме доцільно, оптимальним чином, ознайомлювати 3 цими знаннями студентів-психологів, ані викладу досвіду подібної роботи, не знайдено. Оскільки наявні відомості не дають цілісної картини явища, що перебуває у центрі розгляду, видається доцільною розробка відповідного підходу, який би дозволив студентам не лише опанувати наявні теоретичні знання, але й практичні способи дослідження самосвідомості, а також висвітлив можливості застосування цих знань. Врахування даної обставини змушуе до проведення самостійного дослідження.

Результати власних досліджень. Проведене дослідження полягало у реалізації спроби розробити й апробувати раціональний підхід до ознайомлення студентів із дослідженням самосвідомості, який би дозволив поеднати наявні знання 3 даної теми на певній оптимальній основі, подати ïx доступно й у відповідній логічній послідовності, виходячи з їхніх потреб у таких знаннях, наявного рівня знань і чинних вимог професійної підготовки психологів. Базові засади застосування дослідницького підходу при вивченні психологічних дисциплін майбутніми фраховими психологами з'ясовані раніше і викладені в окремій публікації [2]. У проведеному дослідженні передбачено як аналітичну, так і практичну складову; воно організовуеться та проводиться викладачем, проте 3 максимально можливим залученням студентів. Традиційний виклад матеріалу під час занять із освоєння даної теми не планувався; натомість передбачено, що перед заняттями студенти повинні ознайомитися з матеріалом кожної наступної лекції, розміщеним у Віртуальному навчальному середовищі закладу. Під час занять передба- чалося здійснити його опрацювання: з'ясування незрозумілих положень, уточнення та конкретизащію певних ньюансів, наприклад, у вигляді бесіди чи диспуту тощо. Студенти повинні були виявити вміння самостійно опрацьовувати матеріал, призначений для вивчення, а також залучитися до процесу розгляду питань, що вивчаються. Запропонований підхід апробовано при викладанні курсу «Загальна психологія» студентам, які навчаються за спеціальністю «Психологія», на 1-му курci в Національному університеті «Львівська політехніка». Вироблена оптимальна послідовність проведення дослідження, як подача й опрацювання теоретичного матеріалу, так і його практична складова, в скороченому вигляді, наведені далі.

Аналітична частина дослідження. Розпочати розгляд теми потрібно зі з'ясування сутності поняття “самосвідомість”, передусім відзначивши наступне: усвідомлення людиною світу не зводиться до відображення лише зовнішніх об'ектів, оскільки фокус свідомості може бути спрямовано і на саму людину, їі власну діяльність, внутрішній світ. Процес усвідомлення людиною самої себе, своїх властивостей і якостей зазивається самоусвідомленням. У результаті самоусвідомлення формуеться самосвідомість - сукупність властивостей, що характеризують усвідомлення людиною самої себе, своїх стосунків з іншими людьми, мотивів власних дій і вчинків, своїх особистісних якостей. Необхідно надати визначення поняття, при необхідності також пояснення та приклади до нього. Відразу ж варто зробити спробу включити студентів у процес висвітлення та опрацювання теми, для цього можна поставити питання: наскільки вписуеться дане поняття у їхню систему знань, що формуються? Які відомі інші його визначення? У чому полягають відмінності між ними тощо.

Далі констатуемо, що самосвідомість не $є$ вродженою характеристикою людини, а формуеться поступово, проходячи наступні етапи: самовідчуття - самосприймання - саморозуміння. На основі сформованих уявлень і знань про свою особистість виникае складне психічне утворення, яке отримало назву «Я-концепція»; до наведеного даємо необхідні пояснення та коментарі.

Після цього розглядаємо питання про функції та структуру самосвідомості. Кожен із їі компонентів також вимагає окремого розгляду, відтак послідовно розповідаємо про: образ «ЯҢ, самоощінку, рівень домагань і психологічний захист. Різні види психологічного захисту також потребують окремого висвітлення та наведення прикладів. Ступінь розуміння висвітлених питань можна з'ясувати, залучивши до процесу опрацювання матеріалу студентів, доречно також влаштувати дискусію з приводу предмету розгляду.

Підбиваючи проміжні підсумки, слід наголосити на тому, що самосвідомість - не першочергова даність, притаманна людині, а продукт розвитку. При цьому вона не має своеї окремої від особистості лінії розвитку, а включається як сторона в процес іiї реального формування. В ході цього розвитку, в міру того, як людина набуває життевий досвід, перед нею відкриваються нові сторони буття, здійснюеться глибоке переосмислення життя. Даний процес його переосмислювання, що проходить через все життя людини, утворюе основний зміст ії сутності, визначає мотиви її дій і внутрішній зміст 
тих завдань, які вона вирішуе в житті. Варто також з'ясувати розуміння цього положення студентами.

Наступне завдання зводиться до констатації: складовою самосвідомості є профресійна самосвідомість - усвідомлення людиною себе як суб'єкта пращі, придатності власних якостей, здібностей, соціальної значущості до виконання професійних обов'язків. Це психологічний показник успішності продресійного розвитку особистості. Разом з цим професійна самосвідомість - це важливий механізм, що забезпечуе саморегулящію профресійного становлення, який ефрективно фрункціонуе при наявності високого рівня самосвідомості, здатності адекватно ощінювати свої досягнення, помилки і невдачі. Тут варто влаштувати дискусію про перебіг процесу профресійного становлення присутніх, майбутніх психологів, із врахуванням розглянутих положень.

У наступних питаннях необхідно розглянути не менш важливі положення, про: самоповагу та комплекс меншовартості; самореалізацію особистості; розвиток самосвідомості. Не завершення викладу потрібно висвітлити питання про можливості діагностики складових самосвідомості. Після обговорення розглянутих питань, здійснення необхідних узагальнень та окреслення подальших перспектив вивчення теми аналітичну частину можна завершити. Далі можна переходити до практичної частини, яка надає значно більші можливості для проведення дослідження.

Практична частина дослідження. Полягає у демонстрації можливостей роботи зі самосвідомістю у практиці фрахового психолога: як особливостей прояву, так і діагностики наявного стану та формування складових; виконуеться, головним чином, під час практичних занять. Проте передбачена також можливість, за необхідності, задавати студентам індивідуальні творчі завдання для позааудиторної роботи.

1. Студентам запропоновано здійснити спостереження за вмістом власної свідомості протягом фріксованого проміжку часу; необхідно охарактеризувати всі виявлені психічні явища. Після цього здійснюеться опрацювання отриманих результатів, їхне оголошення й обговорення.

2. Фіксація потоку свідомості: необхідно записати вміст свідомості за фріксований відтинок часу. Поставлено завдання подати вміст свідомості у вигляді звіту. Бажаючі оголошують отримані результати, після чого слід влаштувати обговорення й зробити узагальнення.

3. Наступне завдання присутнім: зафіксувати внутрішній монолог - у вигляді потоку думок, наявних у свідомості. Спробувати встановити, чим вони спричинені та як взаємопов'язані. Після цього необхідно оголосити результати та здійснити їхній аналіз.

4. Дослідження самооцінки: студентам запропоновано виконати тест на визначення рівня самооцінки. Для цього необхідно виконати поставлене завдання, згідно з відповідною методикою. Відтак здійснюеться опрацювання отриманих результатів, за стандартизованою процедурою; результати інтерпретуються й обговорюються.

5. Дослідження рівня домагань. Студентам потрібно виконати завдання тесту, що передбачає з'ясування наявного рівня домагань. Поміркувати 3 приводу: як він був сформований? Після цього здійснюеться опрацювання отриманих результатів, за стандартизованою процедурою; результати інтерпретуються і обговорюються.

6. Дослідження власних механізмів психологічного захисту. Необхідно виявити їхню наявність та охарактеризувати прояви у різних ситуаціях. Навести приклади та здійснити їхній аналіз. Результати необхідно оголосити та влаштувати обговорення.

7. Скласти характеристику власної Я-концепції. Що вона відображає? Яке їі призначення? Які їі індивідуальні особливості? Як вона проявляеться у різних ситуаціях? Як фрункціонує? Наведіть приклади та проаналізуйте їх.

8. Завдання присутнім: складіть перелік основних проблем із самосвідомістю, з якими можуть звертатися клієнти до фрахового психолога. Наведіть приклади: як із власного досвіду, так і 3 інших джерел. Поміркуйте: як вони виникають і які можливі шляхи їнього вирішення?

9. Завдання: скласти характеристику власної профресійної самосвідомості та іiі складових. Як вона сформувалася? Що вплинуло на їі формування? Які їі сильні сторони та недоліки? Результати оголошуються, обговорюються й узагальнюються.

10. Складіть програму розвитку власної профресійної самосвідомості до рівня, необхідного для успішного виконання профресійної діяльності. Які пункти повинна містити така програма? Які особливості її виконання? Чи достатньо вам одержаних під час занять знань для реалізації такої програми? Результати виконання завдання обговорюються.

Головним результатом проведеної навчально-досліднищької роботи стало те, що студенти не лише краще зрозуміли роль самосвідомості у повсякденному житті, навчальній і професійній діяльності, їі призначення та роль окремих складових, а також з'ясували можливості розвитку та застосування одержаних знань у майбутній діяльності за обраним фрахом. Вони опанували підходи і теорії, з якими ознайомилися на лекщійних заняттях, у практичній діяльності, яка наближена до повсякденної роботи психолога. В подальшому робота над даною темою буде продовжуватися, передусім, на старших курсах, та під час вивчення інших навчальних дисциплін.

Проведене дослідження дає підстави зробити наступні висновки.

1. Огляд публікацій за темою дослідження дозволив встановити, що в працях науковців наявні відомості, котрі дозволяють обгрунтувати і реалізувати дослідницький підхід до вивчення самосвідомості у навчальній роботі зі студентами.

2. Застосування запропонованого підходу для викладання майбутнім психологам даної теми створюе необхідні умови для формування необхідних знань, вмінь та навичок, а також допомагає дослідити самосвідомість, що дозволяе подолати труднощі, котрі виникають під час вивчення даної теми.

3. Впровадження розробленого підходу до вивчення самосвідомості допомагає підняти інтерес до даної теми у студентів, що дозволяе оптимізувати процес набуття знань, активізувати розвиток вмінь і навичок, і має позитивний вплив на формування їхньої профресійної самосвідомості.

В майбутньому передбачено здійснити подальше вдосконалення запропонованого підходу, враховуючи результати його апробації, та поширити його застосування до вивчення інших навчальних дисциплін. 


\section{Список літератури:}

1. Бернс Р. Развитие Я концепции и воспитание. Москва : Прогресс, 1986. 468 с.

2. Вінтюк Ю.В. Дослідницький підхід у підготовці майбутніх психологів. Збірник наукових праць Національної акаделї̈ Державної прикордонної служби України. Серія : педагогічні науки. 2020. № 1(20). С. 27-49.

3. Гуменюк О.Є. Психологія Я-концепції : Навчальний посібник. Тернопіль : Економічна думка, 2004.310 с.

4. Захарова А. Структурно-динамическая модель самооценки. Вопросы психологии. 1989. № 1. С. 5-14.

5. Ковальчук П., Онишко А., Петровська О. Педагогічна психологія : навчальний посібник. Львів : Трембіта, $2003.584 \mathrm{c}$.

6. Кон И. В поисках себя : личность и ее самосознание. Москва : Политиздат, 1984. 358 с.

7. Максименко С. Д. Загальна психологія. Навч. посібник. Київ : Центр учбової літератури, 2008. 272 с.

8. Митина Л. Личностное и профессиональное развитие человека в новых социальноэкономических условиях. Вопросы психологии. 1997. № 4. С. 28-38.

9. Морозова О. Розвиток професійної самосвідомості у студентів: психолого-педагогічний аспект. Актуальні питання гуманітарних наук. 2015. № 13. С. 124-129.

10. Мясоїд П.А. Курс загальної психології. Підручник у 2-х т. Київ : Алерта, 2011, 2013.

11. Орлова И.В. Тренинг профессионального самосознания: теория, диагностика и практика педагогической редлекси. Санкт-Петербург : Речь, 2006. 128 с.

12. Психология самосознания ; Под ред. Д.Я. Райгородского. Самара : Издательский Дом «БАХРАХ-М», 2007. 672 с.

13. Рубинштейн С.Л. Основы общей психологии. Санкт-Петербург : Питер, 1999. 720 с.

14. Савчин М.В. Загальна психологія. Навч. посібник. Київ : ВЦ «Академія», 2020. 344 с.

15. Спиркин А. Сознание и самосознание. Москва : Просвещение, 1972.538 с.

16. Столин В. Самосознание личности. Москва : МГУ, 1983. 264 с.

17. Терлецька Л.Г. Технологія самоаналізу. К.: Главник, 2005. 96 с. (Серія: Психологічний інструментарій).

18. Тітаренко О. Розвиток моральної самосвідомості студентів гуманітарних фракультетів. Київ : Наука, 2003.364 с.

19. Цукерман Г., Мастеров Б. Психология саморазвития. Москва : Просвещение, 1995. 388 с.

20. Чеснокова И. Проблема самосознания в психологии. Москва : Наука, 1977. 384 с.

\section{References:}

1. Berns, R. (1986). Razvytye Ya kontseptsyy y vospytanye [Development of self concept and education]. Moskow: Prohress, 468 p. (in Russian)

2. Vintiuk, Yu.V. (2020). Doslidnytskyi pidkhid u pidhotovtsi maibutnikh psykholohiv [Research approach in the training of future psychologists]. Zbirnyk naukovykh prats Natsionalnoi akademii Derzhavnoi prykordonnoi sluzhby Ukrainy. Seriia: pedahohichni nauky, no. 1(20), pp. 27-49. (in Ukrainian)

3. Humeniuk, O.Ye. (2004). Psykholohiia Ya-kontseptsii [Psychology of self-concept]: Navchalnyi posibnyk. Ternopil: Ekonomichna dumka, 310 p. (in Ukrainian)

4. Zakharova, A. (1989). Strukturno-dynamycheskaia model samootsenky [Structural-dynamic self-assessment model]. Voprosy psykholohyy, no. 1, pp. 5-14. (in Russian)

5. Kovalchuk, P., Onyshko, A., \& Petrovska, O. (2003). Pedahohichna psykholohiia [Pedagogical psychology]: navchalnyi posibnyk. Lviv: Trembita, 584 p. (in Ukrainian)

6. Kon, Y. (1984). V poyskakh sebia: lychnost y ee samosoznanye [In Search of Oneself: Personality and Its SelfConsciousness]. Moskow: Polytyzdat, 358 p. (in Russian)

7. Maksymenko, S.D. (2008). Zahalna psykholohiia [General Psychology]. Navch. posibnyk. Kyiv: Tsentr uchbovoi literatury, 272 p. (in Ukrainian)

8. Mytyna, L. (1997). Lychnostnoe y professyonalnoe razvytye cheloveka v novykh sotsyalnoekonomycheskykh uslovyiakh [Personal and professional development of a person in the new socio-economic conditions]. Voprosy psykholohyy, no. 4, pp. 28-38. (in Russian)

9. Morozova, O. (2015). Rozvytok profesiinoi samosvidomosti u studentiv: psykholoho-pedahohichnyi aspekt [Development of professional self-awareness in students: psychological and pedagogical aspect]. Aktualni pytannia humanitarnykh nauk, no. 13, pp. 124-129. (in Ukrainian)

10. Miasoid, P.A. (2011, 2013). Kurs zahalnoi psykholohii [General psychology course]. Pidruchnyk u 2-kh t. Kyiv: Alerta. (in Ukrainian)

11. Orlova, Y.V. (2006). Trenynh professyonalnoho samosoznanyia: teoryia, dyahnostyka y praktyka pedahohycheskoi refleksy [Professional self-awareness training: theory, diagnosis and practice of pedagogical reflexion]. SanktPeterburg: Rech, 128 p. (in Russian)

12. Psykholohyia samosoznanyia (2007) [Psychology of self-awareness]. Pod red. D.Ya. Raihorodskoho. Samara: Yzdatelskyi Dom «BAKhRAKh-M», 672 p. (in Russian)

13. Rubynshtein, S.L. (1999). Osnovy obshchei psykholohyy [Fundamentals of General Psychology]. Sankt-Peterburg: Pyter, 720 p. (in Russian)

14. Savchyn, M.V. (2020). Zahalna psykholohiia [General Psychology]. Navch. posibnyk. Kyiv: VTs "Akademiia», 344 p. (in Ukrainian)

15. Spyrkyn, A. (1972). Soznanye y samosoznanye [Consciousness and self-awareness]. Moskow : Prosveshchenye, 538 p. (in Russian)

16. Stolyn, V. (1983). Samosoznanye lychnosty [Self-awareness of personality]. Moskow: MHU, 264 p. (in Russian)

17. Terletska, L. H. (2005). Tekhnolohila samoanalizu [Technology of introspection]. Kyiv: Hlavnyk, 96 p. (in Ukrainian)

18. Titarenko, O. (2003). Rozvytok moralnoi samosvidomosti studentiv humanitarnykh fakultetiv [Development of moral self-consciousness of students of humanities faculties]. Kyiv: Nauka, 364 p. (in Ukrainian)

19. Tsukerman, H., \& Masterov, B. (1995). Psykholohyia samorazvytyia [Self-development psychology]. Moskow: Prosveshchenye, 388 p. (in Russian)

20. Chesnokova, Y. (1977). Problema samosoznanyia v psykholohyy [The problem of self-awareness in psychology]. Moskow: Nauka, 384 p. (in Russian) 